\title{
Pengaruh Zakat Produktif Terhadap Penanggulangan Kemiskinan Pada Program Pemberdayaan Ekonomi Mustahik di Baznas Kota Palopo
}

\author{
Nur Amal Mas ${ }^{1 *}$, Muh. Darwis ${ }^{1}$, Fasiha ${ }^{1}$ \\ ${ }^{1}$ IAIN Palopo, Indonesia \\ *Korespondensi: nuramalmas@iainpalopo.ac.id
}

\begin{tabular}{c}
\hline Info Artikel \\
\hline Diterima 10 \\
Januari 2022 \\
Disetujui 09 \\
Februari 2022 \\
Dipublikasikan 12 \\
Februari 2022 \\
\hline Keywords: \\
Modal Kerja; \\
Pembinaan \\
Keterampilan SDM; \\
Penanggulangan \\
Kemiskinan \\
\hline
\end{tabular}

(C) 2022 The Author(s): This is an open-access article distributed under the terms of the Creative Commons

Attribution ShareAlike (CC BYSA 4.0)

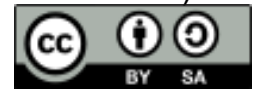

\section{Abstrak}

Penelitian ini memiliki tujuan untuk mengetahui peranan modal usaha dan pembinaan keterampilan Sumber Daya Manusia (SDM) terhadap penanggulangan kemiskinan melalui Program Pemberdayaan Ekonomi Mustahik di BAZNAS Kota Palopo dengan cara simultan dan cara parsial. Instrumen pengumpulan data pokok dengan menggunakan daftar pernyataan yang diuji dengan uji validitas serta reabilitas. Adapun metode analisis yang pergunakan yakni analisis jalur (Path Analisis), pertamatama melakukan konversi data dari skala ordinal menjadi skala interval melalui Method Successive Interval (MSI). Objek dalam penelitian ini berupa modal usaha dan pembinaan keterampilan SDM. Pengujian hipotesis dalam penelitian ini memperlihatkan bahwa Modal Usaha (X1) secara parsial tidak berpengaruh dan tidak signifikan terhadap Penanggulangan Kemiskinan (Y) sebesar 20,4\%. Hasil pengujian hipotesis juga menunjukan bahwa Pembinaan Keterampilan SDM (X2) secara parsial tidak berpengaruh serta tidak signifikan terhadap Penanggulangan Kemiskinan (Y) sebesar 34,4\%. Berdasarkan hasil hipotesis menunjukkan bahwa Modal Usaha (X1) dan Pembinaan Keterampilan SDM (X2) secara simultan berpengaruh positif dan signifikan terhadap Penanggulangan Kemiskinan (Y) melalui Program Pemberdayaan Ekonomi Mustahik di BAZNAS Kota Palopo sebesar 15.4\%. Sedangkan sebesar $84,6 \%$ dipengaruhi oleh variabel lain yang tidak diteliti dalam pelaksanaan penelitian ini.

\section{Abstract}

This study aims to determine the role of venture capital and the development of Human Resources (HR) skills on poverty alleviation through the Mustahik Economic Empowerment Program at BAZNAS Palopo City by simultaneous and partial methods. The main data collection instrument uses a list of statements that are tested with validity and reliability tests. The analytical method used is path analysis, first of all converting data from an ordinal scale to an interval scale through the Successive Interval (MSI) Method. The object of this research is business capital and human resource skills development. Hypothesis testing in this study shows that Business Capital (X1) partially has no effect and is not significant for Poverty Alleviation ( $Y$ ) by $20.4 \%$. The results of hypothesis testing also show that HR Skills Development (X2) partially has no effect and is not significant for Poverty Alleviation $(Y)$ by $34.4 \%$. Based on the results of the hypothesis, it shows that Business Capital (X1) and HR Skills 
Development (X2) simultaneously have a positive and significant effect on Poverty Reduction (Y) through the Mustahik Economic Empowerment Program at BAZNAS Palopo City by $15.4 \%$. Meanwhile, $84.6 \%$ is influenced by other variables not examined in the implementation of this research.

\section{Pendahuluan}

Zakat produktif merupakan resources yang penting dalam mendukung upayaupaya pengentasan kemiskinan. Jumlah penduduk Kota Palopo yang berada pada bawah garis kemiskinan dan terus menurun sejak tahun 2017 dengan persentase 8,78 persen, kemudian pada 2018 turun menjadi 7,94 persen, selanjutnya pada tahun 2019 turun lagi menjadi 7,82 persen. Memasuki tahun 2020, angka kemiskinan di Kota Palopo kembali meningkat menjadi 7,85 persen atau sebesar 14,71 juta penduduk. Peningkatan jumlah serta persentase penduduk miskin di Kota Palopo, disebabkan oleh meningkatnya harga barangbarang kebutuhan pokok berupa beras, gula pasir, telur ayam ras, daging ayam, serta minyak goreng sebagai akibat dari kenaikan harga BBM dan juga meluasn ya pandemi wabah Covid-19 (B. K. Palopo, n.d.)(B. P. S. K. Palopo, 2021). Selama ini, pemerintah Indonesia telah memiliki program-program pengentasan kemiskinan yang dikucurkan selama mewabahnya Covid-19. Diantaranya bantuan langsung tunai (BLT), bantuan stimulus dan program peningkatan u saha mikro dan social preneur dana zakat (Ferezagia, 2018; Saputra, 2021; Sembiring et al., 2020). Program-program tersebut ditempuh pemerintah agar penduduk mampu bertahan hidup serta untuk menekan angka kemiskinan yang semakin akutkarena pandemi.

Terdapat dua kelompok studi tentang pengentasan kemiskinan selama mewabahnya Corona Virus Disease 2019 (Covid-19) menurut aktornya. Pertama, upaya Pemerintah dalam mengemban penyelamatan kesehatan penduduk serta perekonomian nasional, yang terfokus pada anggaran belanja untuk keperluan kesehatan, jaring pengaman sosial (social safety net), dan juga pemulihan keadaan perekonomian termasuk untuk aktivitas dunia usaha dan diberikan pula kepada masyarakat yang terdampak (Pemerintah Republik Indonesia, 2019). Kedua, inisiatif masyarakat sipil melalui institusi-institusi sosial seperti Organisasi Pengelola Zakat (OPZ), sebagaimana yang ditegaskan oleh Umer Chapra bahwa zakat memiliki tujuan yang tidak hanya sekedar memberikan santunan kepada orang miskin secara konsumtif, namun zakat juga mempunyai orientasi yang lebih permanen dalam jangka panjang, yaitu bertujuan mengentaskan kemiskinan yang merupakan nilai strategis zakat produktif (Efendi, 2017). Oleh sebab itu zakat menjadi sebuah upaya dan alternatif dalam menolong masyarakat yang tergolong miskin sehingga kesulitan dan kemiskinan yang meningkat akibat pandemi Covid19 dapat direduksi dengan signifikan.

Sebagaimana yang jelaskan oleh Hafidhuddin (2005) bahwa beberapa ulama seperti Imam Syafi'i dan An-Nasa'I menjelaskan bahwa Mustahik penerima zakat yang mempunyai kemampuan dalam bidang bisnis layak untuk diberikan modal usaha sehingga dengan begitu akan memperoleh penghasilan yang mampu mencukupi kebutuhan pokok pribadi dan keluarganya. Kemudian Mustahik yang memiliki keterampilan tertentu (skills) dapat diberikan bantuan modal berupa peralatan maupun perlengkapan usaha untuk mengembangkan sebuah usaha 
berdasarkan keterampilan yang dimiliki.(Y. C. Pratama, 2015). Program zakat produktif yang terdapat pada Badan Amil Zakat Nasional secara umum terbagi atas dua bentuk: pertama, zakat diberdayagunakan untuk mendukung insentif bekerja atau mencari penghasilan secara mandiri di kalangan masyarakat Mustahik. Kedua, untuk mendanai aktivitas usaha produktif Mustahik yang membutuhkan, diantaranya pendayagunaan zakat produktif dalam mendanai kegiatan-kegiatan pembinaan skills sumber daya manusia (SDM) serta pelatihanpelatihan yang dapat meningkatkan keahlian Mustahik, bantuan tambahan modal awal, atau pemberian modal kerja. Jika pemberian modal kerja atau bantuan modal awal serta mendanai berbagai pelatihan dan kegiatan yang mengasah keterampilan Mustahiq melalui pendayagunaan zakat produktif, akan dapat membantu program pemerintah dalam menanggulangi kemiskinan, memeratakan distribusi pendapatan serta memperkecil jurang kesenjangan antara golongan kaya dan miskin (Rahmawaty, 2013). yang menjadi masalah krusial di Indonesia terutama di Kota Palopo.

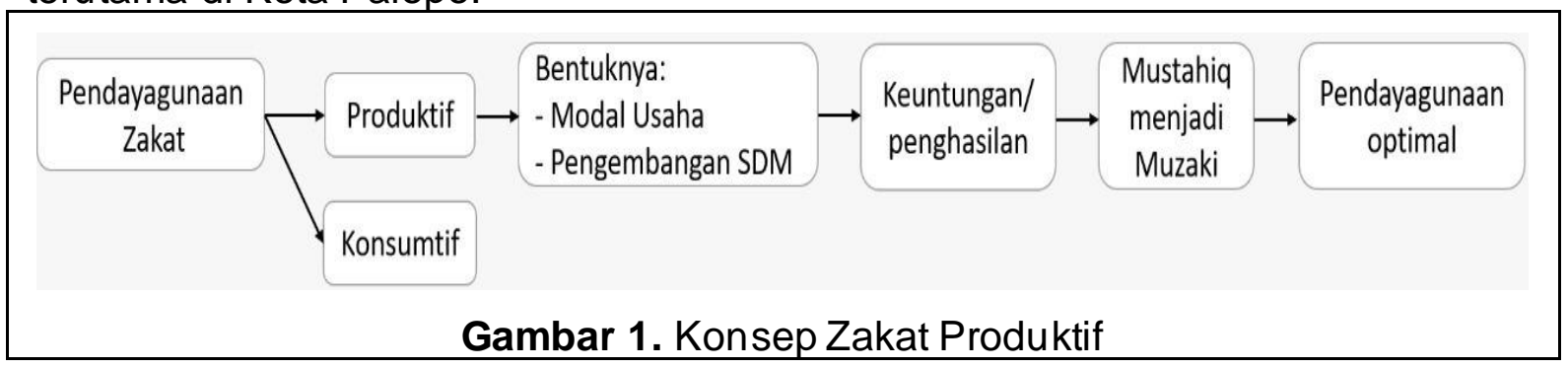

Sumber: (Setiawan, 2016)

Adapun selama ini dampak pendayagunaan zakat produktif terhadap upaya penanggulangan kemiskinan belum banyak dibahas. Tulisan ini ditujukan dalam rangka melengkapi kekurangan yang ada pada studi terdahulu yang hanya membahas penyaluran dana zakat secara umum terhadap pengentasan kemiskinan(Desi Ariani \& Moch.Anwar, 2018; Y. C. Pratama, 2015)(Adnan \& Roselam, 2018). Sedangkan penelitian ini khusus membahas pengaruh zakat produktif $(\mathrm{X})$ terhadap penanggulangan kemiskinan Mustahik $(\mathrm{Y})$ dengan cara menganalisis sub variable zakat produktif berupa bantuan modal usaha (X1) dan pembinaan keterampilan sumberdaya manusia (X2) melalui program pemberdayaan ekonomi Mustahiq BAZNAS Kota Palopo. Sejalan dengan itu, tiga pertanyaan dijawab dalam penelitian ini: (a) pengaruh bantuan modal usaha terhadap penanggulangan kemiskinan; (b) pengaruh pembinaan keterampilan sumberdaya manusia terhadap penanggulangan kemiskinan (c) pengaruh zakat produktif secara simultan terhadap penanggulangan kemiskinan. Ketiga pertanyaan tersebut memberi arah bagi pemahaman bahwa zakat produktif tidak hanya menjadi program kesejahteraan pemerintah tetapi juga dapat menjadi solusi dan jalan keluar dari garis kemiskinan sebagaimana tujuan utama penyaluran zakat.

Tulisan ini didasarkan pada suatu alasan atau argument bahwa pembinaan usaha mikro dan keterampilan Mustahik telah memberi pengaruh langsung terhadap pengentasan kemiskinan yang sejalan dengan diberdayakannya zakat produktif. Program pembinaan usaha Mustahik yang signifikan melalui zakat produktif menentukan tingkat penghasilan dan kesejahteraan hidup Mustahik. Kurangnya lapangan kerja dan keterbatasan modal usaha membuat Mustahik tidak mampu mandiri secara finansial. Bantuan modal usaha dan pembinaan 
keterampilan Mustahik yang inklusif merupakan gerbang penanggulangan kemiskinan (F. R. P. Pratama \& Cahyono, 2020). Mustahik yang mengelola bantuan modal usaha dengan sungguh-sungguh disertai pendampingan yang intensif oleh Amil/pengelola zakat produktif maka akan menanggulangi kemiskinan, menyokong pendapatan dan membangun kemandirian ekonomi Mustahik.

\section{Metode Penelitian}

Hubungan antara zakat produktif dengan penanggulangan kemiskinan dijelaskan melalui metode penelitian kuantitatif yang bersandar pada pendekatan penelitian basis survey yakni dalam hal ini penelitian survey dipergunakan dalam rangka mengungkap korelasi kausal serta uji hipotesis. Penelitian ini mmperolehl sampel dengan menggunakan teknik snowball sampling (Algifari, 2016), yakni pengambilan sampel dengan cara berantai dimulai dari satu atau beberapa anggota objek yang diteliti sebagai anggota sampel kemudian diperoleh tambah an sampel lainnya, teknik ini seperti bola salju dimana volumenya semakin lama semakin membesar atau bertambah banyak hingga diperoleh jumlah (ukuran) sampel yang dibutuhkan. Pengumpulan data dalam penelitian ini menggunakan angket yang menjadi alat pengumpul data yang utama atau pokok yang disebarkan kepada para Amil/pengelola Zakat dan Mustahik sebanyak 30 orang.

Penelitian ini menggunakan jenis data kuantitatif dan kualitatif, disisi lain sumber data yang dipergunakan yaitu data sekunder dan data primer. Adapun teknik pengumpulan data yang dipergunakan yaitu kuosioner, dokumentasi, observasi dan wawancara. Sedangkan pengujian instrument dalam penelitian ini menggunakan uji validitas dan uji realibilitas.

Variabel zakat produktif $(X)$ memiliki sub-sub variable yakni modal usaha (X1) dan pembinaan keterampilan SDM (X2). Untuk menyatakan sub-sub variable apakah mempunyai pengaruh terhadap penanggulangan kemiskinan ( $Y$ ) atau tidak, Oleh karena itu pengujian data dilakukan dengan menggunakan uji an alisis jalur (path analisys), dengan pertama-tama melakukan konversi dari data skala ordinal menjadi skala interval dengan cara Method Successive Interval (MSI), kemudian melakukan uji normalitas, uji lineritas, uji multikolinieritas dan uji heterokedastistisitas. Adapun pertimbangan dalam menggunakan analisis jalur yang diaplikasikan dalam penelitian ini karena pola hubungan variabel yang ada bersifat korelatif dan kausalitas.

\section{Hasil}

\subsection{Hasil Uji Validitas dan Reabilitas}

Tabel 1. Uji Validitas dan Reabilitas Modal Usaha (X1)

\begin{tabular}{|c|c|c|c|c|c|c|}
\hline \multirow{2}{*}{ Item } & \multicolumn{3}{|c|}{ Uji Validitas } & Nilai & \multicolumn{2}{|c|}{ Uji Reliabilitas } \\
\hline & r Hitung & $r$ tabel & Ket & Signifikansi & Alpha & Ket \\
\hline $\mathrm{X} 1-1$ & 0.722 & 0,306 & Valid & 0.000 & \multirow{10}{*}{0.896} & \multirow{10}{*}{$\begin{array}{c}>0.6 \\
\quad= \\
\text { reliable }\end{array}$} \\
\hline $\mathrm{X} 1-2$ & 0.730 & 0,306 & Valid & 0.000 & & \\
\hline $\mathrm{X} 1-3$ & 0.691 & 0,306 & Valid & 0.000 & & \\
\hline$\overline{X 1-4}$ & 0.568 & 0,306 & Valid & 0.001 & & \\
\hline $\mathrm{X} 1-5$ & 0.737 & 0,306 & Valid & 0.000 & & \\
\hline $\mathrm{X} 1-6$ & 0.670 & 0,306 & Valid & 0.000 & & \\
\hline $\mathrm{X} 1-7$ & 0.627 & 0,306 & Valid & 0.000 & & \\
\hline $\mathrm{X} 1-8$ & 0.817 & 0,306 & $\begin{array}{l}\text { Valid } \\
\text { Val }\end{array}$ & 0.000 & & \\
\hline $\mathrm{X} 1-9$ & 0.830 & 0,306 & Valid & 0.000 & & \\
\hline $\mathrm{X} 1-10$ & 0.784 & 0.306 & Valid & 0.000 & & \\
\hline
\end{tabular}




\section{Sumber: Hasil Olah Data, 2021}

Berdasarkan tabel diatas maka dapat dijelaskan bahwa seluruh item pernyataan yang terdapat pada variabel modal usaha (X1), seluruh instrumen menunjukkan hasil uji validitas dan reabilitas dinyatakan valid dan juga reliable. Ketentuan tersebut diangkat atas dasar nilai korelasi koefisien rHitung pada setiap item > rtabel $(0,306)$. Sementara itu informasi mengenai koefisien alphanya sebanyak $(0,896>0,6)$, oleh karena itu dapat diartikan bahwa seluruh item pernyataan pada variabel Modal Usaha adalah valid dan reliable.

Tabel 2. Uji Validitas dan Reabilitas Pembinaan Keterampilan SDM (X2)

\begin{tabular}{ccccccc}
\hline \multirow{2}{*}{ Item } & \multicolumn{3}{c}{ Uji Validitas } & \multirow{2}{*}{ Nilai Signifikansi } & \multicolumn{2}{c}{ Uji Reliabilitas } \\
\cline { 2 - 5 } & r Hitung & r tabel & Ket & & Ket \\
\hline X2.1 & 0.748 & 0,306 & Valid & 0.000 & & \\
\hline X2.2 & 0.781 & 0,306 & Valid & 0.000 & & $>0.6$ \\
\hline X2.3 & 0.708 & 0,306 & Valid & 0.000 & 0.717 & $=$ \\
X2.4 & 0.515 & 0,306 & Valid & 0.004 & & reliable \\
\hline X2.5 & 0.706 & 0,306 & Valid & 0.000 & & \\
\hline
\end{tabular}

Sumber: Hasil Olah Data, 2021

Berdasarkan tabel diatas maka dapat dipaparkan bahwa seluruh item pernyataan yang terdapat pada variabel pembinaan keterampilan SDM (X2), seluruh instrumen menunjukkan hasil uji validitas dan reabilitas dinyatakan valid dan juga reliable. Ketentuan tersebut diangkat atas dasar nilai korelasi koefisien rHitung pada setiap item $>$ rtabel $(0,306)$. Sementara itu informasi mengenai koefisien alphanya sebanyak $(0,717>0,6)$, oleh karena itu dapat diartikan bahwa seluruh item pernyataan pada variabel pembinaan keterampilan SDM adalah valid dan reliable.

Tabel 3. Uji Validitas dan Reabilitas Penanggulangan Kemiskinan ( $Y$ )

\begin{tabular}{|c|c|c|c|c|c|c|}
\hline \multirow{2}{*}{ Item } & \multicolumn{3}{|c|}{ Uji Validitas } & \multirow{2}{*}{ Nilai Signifikansi } & \multicolumn{2}{|c|}{ Uji Reliabilitas } \\
\hline & $r$ Hitung & $r$ tabel & Ket & & Alpha & Ket \\
\hline Y1 & 0.702 & 0,306 & Valid & 0.000 & & \\
\hline$\overline{\mathrm{Y} 2}$ & 0.713 & 0,306 & Valid & 0.000 & & \\
\hline Y3 & 0.707 & 0,306 & Valid & 0.000 & & $>0.6$ \\
\hline Y4 & 0.671 & 0,306 & Valid & 0.000 & 0.795 & $=$ \\
\hline Y5 & 0.740 & 0,306 & Valid & 0.000 & & reliable \\
\hline Y6 & 0.499 & 0,306 & Valid & 0.005 & & \\
\hline Y7 & 0.675 & 0,306 & Valid & 0.000 & & \\
\hline
\end{tabular}

Sumber: Hasil Olah Data, 2021

Berdasarkan tabel diatas maka dapat disampaikan bahwa seluruh item pernyataan yang terdapat pada variabel penanggulangan kemiskinan $(Y)$, selu ru $\mathrm{h}$ instrumen menunjukkan hasil uji validitas dan reabilitas dinyatakan valid dan ju ga reliable. Ketentuan tersebut diangkat atas dasar nilai korelasi koefisien rHitung pada setiap item $>$ rtabel $(0,306)$. Sementara itu informasi mengenai koefisien alphanya sebanyak $(0,795>0,6)$, oleh karena itu dapat diartikan bahwa seluruh item pernyataan pada variabel pembinaan keterampilan SDM yakni valid dan reliable. 


\subsection{Analisis Data Statistik}

Persamaan struktural berdasarkan hasil olah data kerangka hubungan kausal antara variabel $\mathrm{X} 1$ dan $\mathrm{X} 2$ terhadap variabel $\mathrm{Y}$ dapat dipaparkan sebagai berikut:

$$
\mathbf{Y}=0.204 \mathrm{X} 1+0.344 \mathrm{X} 2+0.846 \varepsilon
$$

Persamaan tersebut memperlihatkan koefisien variabel independen yaitu Modal Usaha (X1) sebesar 0.204 dan bertanda positif. Kemudian variabel Pembinaan Keterampilan SDM (X2) sebesar 0.344 dan positif. Dengan begitu, hal ini menunjukan bahwa semua variabel indikator yang mengukur Penanggulangan Kemiskinan (Y) memiliki kontribusi yang positif terhadap Penanggulangan Kemiskinan (Y). Maknanya jika sub variabel bantuan modal usaha (X1) dipadukan dengan pembinaan Keterampilan SDM (X2) maka Zakat Produktif (X) akan berpengaruh positif dalam penanggulangan kemiskinan meskipun pengaruhnya hanya 0.154 atau $15.4 \%$ yang merupakan hasil uji hipotesis. Sedangkan angka $\varepsilon=$ 0.846 menunjukkan bahwa terdapat beberapa variabel yang lain dan tidak diteliti didalam penelitian ini sebesar $84.6 \%$. Hubungan antar variabel dapat dilihat dari gambar berikut ini:

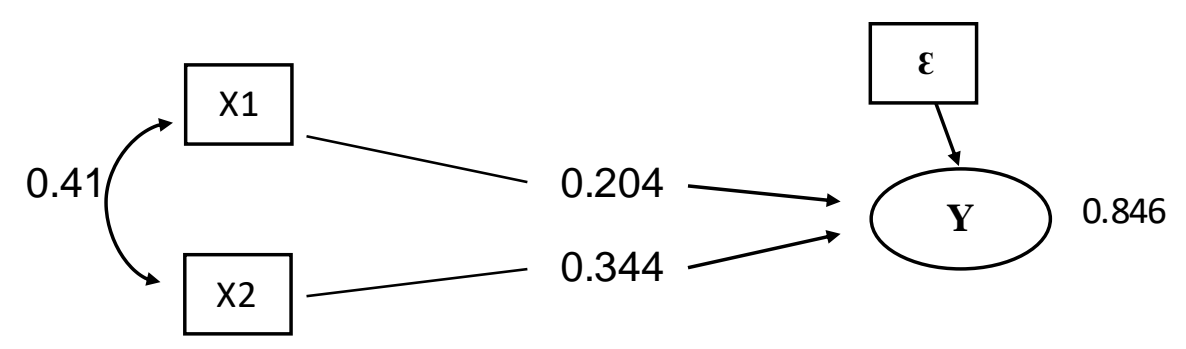

Gambar 2. Hasil Hubungan X1 dan X2 Terhadap $Y$

\subsection{Pengujian Hipotesis}

Hasil olahan data diperoleh bahwa modal usaha memperoleh hasil uji T hitung sebesar 1,108 kemudian $T$ tabel sebesar 2,048 dan mempunyai nilai sig. sebesar 0.277 . Sehingga hasil uji T tersebut menunjukkan nilai T hitung $<\mathrm{T}$ tabel atau $(1,108<2,048)$, kemudian nilai signifikan diperbandingkan dengan nilai probabilitas 0.05 diperoleh nilai probabilitas 0.05 lebih kecil dari pada nilai sig. atau $(0.05<0.277)$, sehingga Ho diterima. Sehingga secara parsial variabel modal usaha (X1) tidak berpengaruh positif dan tidak signifikan terhadap penanggulangan kemiskinan $(\mathrm{Y})$.

Pembinaan keterampilan SDM menunjukkan nilai Thitung sebesar 1,868 dan T tabel sebesar 2,048 dengan nilai sig. sebesar 0,073. Hasil Uji T memampilkan untuk nilai Thitung $<$ T tabel atau $(1,868<2,048)$, kemudian dibandingkan dengan nilai probabilitas 0,05 . Hasil perbandingan menunjukan nilai probabilitas 0.05 lebih kecil dari pada nilai sig. atau $(0,05<0.073)$ maka Ho diterima. Artinya pembinaan keterampilan SDM (x2) secara parsial tidak memiliki pengaruh positif ataupun tidak signifikan terhadap penanggulangan kemiskinan $(Y)$.

Hasil uji F hitung memperlihatkan nilainya sebesar 3,645 sedangkan hasil uji $F$ tabel sebesar 2,558 dengan taraf signifikan yaitu 0,040. Berdasarkan Uji $F$ yang dilakukan menunjukan bahwa $F$ hitung $>F$ tabel atau $(3,645>2,558)$, sedangkan tingkat sig. sebesar $0,040<\alpha=0.05$. Hal ini berarti tingkat kepercayaan sebesar 
95\%, secara simultan (bersama-sama) variabel Modal Usaha (X1) serta Pembinaan Keterampilan SDM (X2) berpengaruh positif dan signifikan terhadap Penanggulangan Kemiskinan $(\mathrm{Y})$ menurut olah data statistic.

\section{Pembahasan}

\subsection{Modal Usaha Secara Parsial Tidak Berpengaruh Terhadap Penanggulangan Kemiskinan}

Hasil penelitian menampakkan tidak terdapat pengaruh dan tidak signifikan antara modal usaha (X1) dan Penanggulangan Kemiskinan (Y). Hal tersebut memperlihatkan adanya pemberian modal usaha kepada Mustahik tidak serta merta mengatasi penanggulangan kemiskinan yang dialami oleh Mustahik binaan BAZNAS Kota Palopo. Hal tersebut disebabkan oleh fakta yang ditemukan bahwa modal usaha yang diberikan berupa uang tunai sebesar 1,5jt - 2,5jt dianggap belum cukup untuk membangun dan mengembangkan usaha Mustahik zakat produktif, pendapatan Mustahik yang tidak tetap, kurangnya kemampuan mengelola dan memutar modal, serta rawannya resiko moral hazard (human eror) sehingga modal yang diperuntukkan untuk usaha produktif digunakan untuk keperluan konsumtif.

Hasil penelitian ini sejalan atau didukung oleh argument Tanjung (2019) dalam hasil penelitiannya yang menerangkan bahwa tidak signifikannya penyaluran dana zakat produktif disebabkan kurangnya nominal dana (modal) zakat yang didistribusikan kepada Mustahik fakir miskin, sejumlah tanggungan atau anggota rumah tangga yang dapat dikatakan lumayan besar juga semakin mengurangi bagian yang diterima perkapita dari jumlah pendapatan yang relatif kecil pula, serta kebutuhan hidup Mustahik yang semakin beragam dan bertambah banyak seperti keperluan konsumsi, biaya air dan listrik, biaya kesehatan dan biaya pendidikan.

\subsection{Pembinaan Keterampilan SDM Secara Parsial Tidak Berpengaruh Terhadap Penanggulangan Kemiskinan}

Temuan penelitian memperlihatkan bahwa tidak terdapat pengaruh dan tidak signifikan antara Pembinaan Keterampilan SDM (X2) terhadap Penanggulangan Kemiskinan ( $Y$ ). Hal tersebut menunjukkan program pelatihan dan pembinaan keterampilan saja tidak cukup sebagai solusi pengurang angka kemiskinan di Kota Palopo. Selain itu, variabel ini merupakan yang paling besar tidak berpengaruh terhadap variabel penanggulangan kemiskinan.

Hal tersebut didasari oleh fakta yang ditemukan di lapangan bahwa pembinaan keterampilan Mustahik di BAZNAS Kota Palopo sangat minim bahkan sangat jarang serta kurang mendapat perhatian dari pihak amil zakat sehingga variabel ini menjadi yang paling tidak berpengaruh terhadap penanggulangan kemiskinan. Pelatihan hendaknya dilaksanakan secara berkesinambungan (step by step), pembinaan keterampilan Mustahik tidak hanya dilaksanakan di kelas pelatihan tetapi juga diperlukan peran pihak Amil untuk turut serta dalam pendampingan dan pembinaan pengelolaan usaha Mustahik untuk meraih kemandirian ekonomi dan mengurangi tingkat kemiskinan Mustahik zakat.

Hal tersebut juga didukung oleh hasil penelitian Rudi (2015) dengan temuan skill atau keterampilan SDM tidak berpengaruh positif dalam artian berpengaruh negatif terhadap penanggulangan kemiskinan. Penelitian ini menerangkan bah wa 
Amil Zakat perlu turut aktif membantu serta mendampingi Mustahik memperoleh pelatihan dan bimbingan keterampilan yang berkaitan dengan kegiatan usaha yang dijalankan oleh para Mustahik.

\subsection{Modal Usaha dan Keterampilan SDM Berpengaruh Positif dan Signifikan Secara Simultan Terhadap Penanggulangan Kemiskinan}

Berdasarkan hasil penelitian yang telah diperoleh dapat disimpulkan bahwa secara simultan terdapat pengaruh langsung positif dan juga signifikan (dapat dipercaya) antara variabel zakat produktif yang berupa subvariabel modal usaha dan keterampilan SDM yang ada BAZNAS Palopo terhadap penanggulangan kemiskinan di Kota Palopo. Selanjutnya temuan dari hasil uji persamaan struktu ral menunjukan bahwa kedua variabel tersebut, memiliki peran dalam membuktikan penanggulangan kemiskinan. Besarnya pengaruh tersebut menunjukkan peranan zakat produktif yang menyandingkan modal usaha dan keterampilan SDM dalam program pemberdayaan ekonomi Mustahik di BAZNAS Kota Palopo memberikan kontribusi dalam upaya penanggulangan kemiskinan di Kota Palopo.

Hasil temuan penelitian ini baik modal usaha maupun pembinaan keterampilan SDM secara parsial tidak memiliki efek signifikan dan tidak berpengaruh terhadap penanggulangan kemiskinan. Artinya jika BAZNAS hanya memberikan bantuan modal usaha saja tanpa disertai pembinaan keterampilan SDM, maka tidak berpengaruh pada pertumbuhan ekononomi Mustahik dan tidak menanggulangi kemiskinan Mustahik. Begitupula jika BAZNAS han ya melakukan pembinaan keterampilan SDM tanpa menyuplay modal baik berupa dana tunai ataupun peralatan, maka tidak berpengaruh pada pengembangan ekonomi Mustahik dan tidak menanggulangi kemiskinan Mustahik. Namun jika kedua variabel modal usaha dan pembinaan keterampilan SDM diberikan secara bersamaan akan berpengaruh positif dan signifikan terhadap penanggulangan kemiskinan pada Mustahik zakat produktif Kota Palopo.

Hasil penelitian yang dilakukan sejalan dengan hasil penelitian Masruroh dan Farid (2019) yang mengungkapkan semakin bertambah kuantitas pengelolaan ZIS yang bersifat produktif, maka pertumbuhan usaha produktif yang dijalankan oleh para Mustahik akan meningkat sehingga angka pengentasan kemiskinan akan meningkat pula. Sebaliknya juga seperti itu, bila pendayagunaan zakat produktif di lingkungan Mustahik BAZNAS kurang, maka pertumbuhan usaha yang dijalankan Mustahik juga akan kurang/rendah sehingga angka pen anggulangan kemiskinan juga rendah. Hal ini disebabkan dengan adanya pendayagunaan zakat produktif membuat Mustahik semangat dalam menjalankan usahanya.

\section{Kesimpulan}

Berdasarkan hasil penelitian ini diproleh kesimpulan bahwa secara parsial variabel modal usaha tidak memiliki pengaruh dan tidak signifikan terhadap penanggulangan kemiskinan Mustahik zakat produktif. Begitupula variabel pembinaan keterampilan SDM secara parsial tidak memiliki pengaruh serta tidak signifikan terhadap penanggulangan kemiskinan Mustahik. Sedangkan secara statistic variabel modal usaha serta pembinaan keterampilan SDM yang diuji secara simultan (bersama-sama) memiliki pengaruh positif dan signifikan terhadap penanggulangan kemiskinan Mustahik zakat produktif melalui program pemberdayaan ekonomi Mustahik Badan Amil Zakat (BASNAS) Kota Palopo. 
Meskipun besaran angka pengaruh zakat produktif melalui variabel modal usaha dan pembinaan keterampilan SDM berpengaruh cukup kecil terhadap penanggulangan kemiskinan, namun melalui penelitian ini zakat produktif telah memberikan dampak nyata dalam upaya pengentasan kemiskinan, zakat produktif menjadi instrumen keuangan yang efektif dalam permasalahan modal dan juga kurangnya keterampilan berwirausaha Mustahiq miskin. Agar program pendayagunaan zakat produktif dapat terlaksana dengan efektif serta permasalahan kemiskinan dapat direduksi diperlukan upaya dan partisipasi dari berbagai pihak seperti Muzakki, badan amil zakat, pemerintah dan masyarakat muslim lainnya agar zakat dapat diberdayakan sesuai dengan potensi dan tujuannya. Selain itu dibutuhkan program-program pendayagunaan zakat produktif lainnya yang tepat sasaran seperti pemberian bantuan binatang ternak serta tersedianya akses distribusi hasil kegiatan produksi/usaha Mustahiq. Kemudian diperlukan juga pendampingan yang sungguh-sungguh secara berkelanju tan oleh Amil zakat mulai dari tahap pendataan Mustahiq penerima program bantuan zakat produktif hingga tahap Mustahiq menjadi Muzakki (orang yang mengeluarkan zakat), mampu mandiri secara ekonomi, meningkatkan kesejahteraan Mustahiq dan membawa Mustahiq keluar dari masalah kemiskinan.

\section{Daftar Pustaka}

Adnan, N. I. M., \& Roselam, M. A. C. (2018). Pengagihan Dana Zakat Dalam Bentuk Pembiayaan Mikro Untuk Usahawan Miskin di Malaysia. Journal of Fatwa Management and Research, 13(1), 1-14.

Algifari. (2016). Statistika Induktif untuk Ekonomi dan Bisnis (2nd ed., p. 351). UPP STIM YKPN. http://inlislite.uin-suska.ac.id/opac/detail-opac?id=5261

Desi Ariani, \& Moch.Anwar. (2018). Program Pemberdayaan Zakat Bagi UMKM Pada Rumah Zakat Kota Surabaya. Jurnal Ekonomi Islam, Fakultas Ekonomi, Universitas Negeri Surabaya, 1(1), 13-24.

Efendi, M. (2017). Pengelolaan Zakat Produktif Berwawasan Kewirausahaan Sosial dalam Mengentaskan Kemiskinan di Indonesia. Al-Ahkam: Jurnall IImu Syari'ah Dan Hukum, 2(1), 21-38.

Ferezagia, D. V. (2018). Analisis Tingkat Kemiskinan di Indonesia. Jurnal Sosial Humaniora Terapan, 1(1), 1-6. https://doi.org/10.7454/jsht.v1i1.6

Masruroh, I., \& Farid, M. (2019). Pengaruh Pengelolaan Ekonomi Produktif dalam Mengentaskan Kemiskinan di Kota Lumajang Studi pada Badan Amil Zakat Nasional (BAZNAS) Kabupaten Lumajang. Iqtishoduna: Jurnal Ekonomi Islam, $8(1)$, 209-229. http://ejournal.iaisyarifuddin.ac.id/index.php/iqtishoduna/article/view/348

Palopo, B. K. (n.d.). Palopo dalam Angka.

Palopo, B. P. S. K. (2021). Kota Palopo dalam Angka. https://palopokota.bps.go.id/publication/2021/02/26/071e5c6cbf16b6c885d9da 00/kota-palopo-dalam-angka-2021.html

Pemerintah Republik Indonesia. (2019). Peraturan Pemerintah Pengganti UndangUndang Republik Indonesia Nomor 1 Tahun 2020 tentang Kebijakan Keuangan Negara dan Stabilitas Sistem Keuangan Untuk Penanganan Pandemi Covid-19 dan/atau Dalam Rangka Menghadapi Ancaman Yang 
Membahayakan Perekonomian N. 2019(1), 46.

Pratama, F. R. P., \& Cahyono, E. F. (2020). Pengukuran Efisiensi Dan Produktivitas Rumah Zakat Indonesia Dengan Metode Indeks Malmquist. Jurnal Ekonomi Syariah Teori Dan Terapan, 6(4), 774. https://doi.org/10.20473/vol6iss20194pp774-786

Pratama, Y. C. (2015). Peran Zakat Dalam Penanggulangan Kemiskinan (Studi Kasus : Program Zakat Produktif Pada Badan Amil Zakat Nasional) [The Role of Zakat in Poverty Alleviation (Case Study: Productive Zakat Program at the National Amil Zakat Board)]. The Journal of Tauhidinomics, 1(1), 93-104.

Rahmawaty, A. (2013). Upaya Pemerataan Kesejahteraan Melalui Keadilan Distributif. Equilibrium, 1(1), 1-17.

Rudi, S. (2015). Rudi, Sugara (11090192), Pengaruh Zakat Produktif, Tenaga Kerja dan Skill terhadap Pendapatan Mustahiq (studi kasus : Lembaga Amil Zakat Semen Padang Kecamatan Lubuk Kilangan) (Vol. 1, Issue 11090192). STKIP PGRI SUMATERA BARAT.

Saputra, R. E. (2021). Peranan Pemerintah Desa Dalam Penyaluran Bantuan Pangan Non Tunai (Bpnt) Pada Masa Pandemi Covid-19 Di Desa Simpang Empat Kecamatan Bebesen Skripsi Oleh: Reza Eka Saputra Fakultas IImu Sosial Dan IImu Politik Universitas Medan Area Medan Peranan Pemeri.

Sembiring, F., Fauzi, M. T., Khalifah, S., Khotimah, A. K., \& Rubiati, Y. (2020). Sistem Pendukung Keputusan Penerima Bantuan Covid 19 menggunakan Metode Simple Additive Weighting (SAW) (Studi Kasus : Desa Sundawenang). Explore: Jurnal Sistem Informasi Dan Telematika (Telekomunikasi, Multimedia Dan Informatika), 11(2), 97-101. https://doi.org/10.36448/JSIT.V11I2.1563

Setiawan, I. (2016). Strategi Pemberdayaan Dana Zakat Produktif Di Baznas Kota Bandung Dalam Meningkatkan Perekonomian Umat. 10.

Tanjung, D. S. (2019). Pengaruh Zakat Produktif Bazna Kota Medan Terhadap Pertumbuhan Usaha dan Kesejahteraan Mustahik di Kecamatan Medan Timur. At-Tawassuth, 4(Jurnal Ekonomi Islam), 349-370. 